\title{
Natural Seeds Accessories as a Form of Sundanese Local Wisdom in Preserving Nature
}

\author{
Santi Susanti \\ Dept. of Television \& Film \\ Fikom Unpad \\ Jatinangor, Indonnesia \\ santisusanti2202@gmail.com
}

\author{
Dian Sinaga \\ Dept. of Information and Library \\ Fikom Unpad \\ Jatinangor, Indonnesia \\ diansinaga@rocketmail.com
}

\author{
Fitri Perdana \\ Dept. of Information and Library \\ Fikom Unpad \\ Jatinangor, Indonnesia \\ peet_lithuania79@ymail.com
}

\begin{abstract}
Local wisdom emerges as a form of human adaptation to the environment. Local wisdom considered as a good environmental preservation instrument. Local wisdom among Sundanese people is always associated with nature, which is to maintain a harmony between humankind and nature. As a part of nature, human beings should not be excessive in exploiting the natural resources. Anthony Sutrisno, a man of Javanese descent, who is attracted by the values of Sundanese local wisdom, preserves those values through the work of accessories he produces. Using name of Bumi Putih Spiritual Jewelry, Anthony communicates his work through various media. This study aims to determine the efforts that Anthony made in communicating the values of Sundanese local wisdom in preserving nature through natural seeds accessories by using the media. This research uses a qualitative method with phenomenology approach. Primary data were collected through in-depth interviews, supported by observation and literature study. The results show that the seeds-based accessories is a form of Anthony's appreciation to Sundanese culture in preserving natural environment. The values of Sundanese local wisdom is applied in the process of making these accessories in a way that does not destroy nature and seed entities. Anthony's accessories have philosophical and economic values in it. To communicate his works, Anthony chose social media (Facebook, Twitter, Instagram, Line). He also made himself as a mobile communication media to promote the works he produced. This study reached to the conclusion that human and nature must respect each other, in order to made life in balance. Utilization of natural potentials tailored to the needs, not to over-exploited. Mankind must be able to control themselves, so as not to harm themselves and natural environment.
\end{abstract}

Keywords - local wisdom, in harmony with nature, Sundanese culture, social media

\section{INTRODUCTION}

Every local community has local wisdom as a form of human adaptation to the natural environment. Local wisdom is a sociocultural condition which contained cultural values that appreciate and adaptive to the natural surroundings, and arranged constantly in a custom order of a society. For the traditional society, local wisdom is the best instrument for environment conservation (Hidayat, 2005).

The term local wisdom was first introduced by $\mathrm{HG}$. Quaritch Wales (in Budiwiyanto, 2006) which refer to local knowledge as the local genius, which means a number of cultural characteristics that shared by a society as a result of the experiences in the past. The system of local wisdom among the Western world is usually called indigenous knowledge (Warren, in Adimiharja, 2004). The concept of local wisdom or traditional knowledge or a system of local knowledge is the characteristic knowledge belongs to a society or a particular culture that has been growing for a long time as a result of the process of reciprocal relationship between the society and the environment. (Marzali, in Mumfangati, et al., 2004).

The concept of local wisdom is rooted in traditional knowledge and management systems that are related to the closeness of the relationship between humans and the environment and natural resources. Through the piloting process, local communities have developed an understanding of the ecological systems at their sites by sustaining natural resources and abandoning activities considered harmful to the environment (Mitchell, 2003).

Forms of local wisdom that exist in society according to Aulia and Dharmawan (2010) can be values, norms, beliefs, and special rules. This diverse form has resulted in the functioning of local wisdom to be diverse as well, for example: (1) preservation and conservation of natural resources; (2) developing human resources; (3) development of culture and sciences; and (4) guidance on advice, beliefs, literature, and abstinence.

The Sundanese also have their own views on human relationships with nature. M. Zaini Alif, a young Sunda practitioner and cultural expert, in a discussion on the ethnology and culture of the Sundanese community, held by the Commonroom on March 5, 2009, revealed, in the text Siksa Kandang Karesian there is the phrase, "Eat is not just hungry, drinking is not just thirst, just cultivating enough to eat. "In this context, the life of the Sundanese is recommended for the "siger tengah" or siniger tengah (the middle way), which means no shortage but not excessive. Not at all for luxury, but just to fulfill daily needs. Thus does not exhaust or exploit nature in excess to maintain its sustainability.

In the Sundanese view, local wisdom is always interpreted by maintaining the harmony of the relationship between human and nature, because between them is an integral part and equally created by God. Thus, human beis should respect nature, not through exploitation in its utilization.

This concept is manifested by an individual of Javanese descent named Anthony Imanuel Alexander Sutrisno, who 
utilizes the natural resources of Sunda, in the form of seeds, which is processed into a work of fashion accessories worth of art as well as economic value. The work produced by Anthony is a form of appreciation of Sundanese culture. The values of local wisdom associated with preserving nature, made Anthony through the process he lived in producing accessories. The process is done naturally, from the stage of collecting seed material to processing into accessories.

Anthony avoid behaviors that harm the natural surroundings. Seeds are collected by picking up that fell to the ground, not plucking directly from the tree. Processing into accessories was done naturally without chemicals, because Anthony believes, the seeds are living things so that treat the seeds and plants producers well is one of life form in harmony with nature and fellow beings. Seeds are collected and then processed and strung using nylon thread with rope techniques to necklaces, bracelets, key chains, beads, rosaries and various other accessories.

For Anthony, the Internet is an opportunity to communicate the results of his work more widely, in addition he followed the exhibition and endorse some artists and artists who are interested in his works. He also utilizes various social media as an interactive communication media with followers and friends on social networking.

Based on the exposure, this study aims to uncover the efforts made by Anthony in communicating the values of local wisdom of Sundanese culture and economic value in his work through the chosen media.

\section{A. About Social Media}

Andreas Kaplan and Michael Haenlein (2010) define social media as "A group of internet-based applications that build on the foundation of Web 2.0 ideology and technology, and which enables the creation and exchange of usergenerated content". Social media is also known as a social networking site, which allows users to connect by creating personal information so that it can connect with others. Personal information can be either a photo or writing.

In social media, anyone can create a personal web page, then connect with friends to share information and communicate. Social media use the internet. Social media invites anyone interested in participating by contributing and feedback openly, commenting, and sharing information in quick and unlimited time.

As internet and mobile phone technology is getting more advanced, social media also grows rapidly. Now to access facebook or twitter for example, can be done anywhere and anytime just by using a mobile phone. So fast people can access social media resulting in a big phenomenon against the flow of information not only in developed countries, but also in Indonesia. Social media or social networking, commonly known and used among others are Blog, Facebook, Twitter, Instagram, Google Plus, Path, Line. In practice, Anthony used some of these media to communicate the results of his work..

\section{RESEARCH METHOD}

The method used in this research is qualitative with phenomenology approach. Qualitative research by Bogdan and Taylor (in Moleong, 2006: 4) is a research procedure that produces descriptive data in the form of written and oral words of people and observed behavior. Facts, information or events become an early reference in qualitative research.

According to Polkinghorne (1989) in Creswell (1998: 51), phenomenological research explains or reveals the meaning of experience that some individuals perceive about concepts or phenomena from the point of view of those who experience them. Thus, the meaning that appears will vary. The key to the discovery of truth is in the subjects studied or the person who found the problem. (Bajari, 2009: 75, Pascasarjana Unpad) In this paper, the author explores Anthony's experience in communicating the values of local wisdom of Sundanese culture through his work in various media.

Maxwell in Alwasilah (2008: 147) explains that in a qualitative research, the number of informants is not a problem, importantly, the informant reflects the uniqueness of the background, the individual and his activities. Informant of this research is Anthony Imanuel Alexander Sutrisno, an artist and designer of craft accessories from natural seeds.

Data analysis was done by inductively analyzing using data analysis technique from Miles and Huberman. The data is reduced, delivered the results and drawn conclusions. Data is presented in a series of interpretative narrative sentences.

\section{RESUlt AND DISCUSSION}

\section{A. The Accessories as a Form of Local Wisdom}

Anthony's behavior in maintaining relationship with the nature is not an instant process. He learnt the Sundanese culture independently.

"I like Sundanese since 2009. I am looking for what Sundanese culture is like. What I'm looking for is more to its values. Sunda I was looking for is more to Sunda wiwitan Before the entry of religion. Like how the original people interacted, living in the land of Sunda."

From seeds, Anthony learns to appreciate nature and learn to appreciate life. Anthony makes the environment as a place to learn many things, including for the discovery of ideas that will be used for his work. For Anthony, the accessories he produced simply represent his appreciation of the Sundanese culture. Seeds are collected from the forest in Tahura Ir. H. Juanda and a number of places in Bandung. Seeds he collected, among others, ganitri seeds, hanjeli, ki sabun and ki oray.

The selection of seeds that Anthony used to work was inspired by seed artists in Bandung, named Bah Gopal, a craftsman who first raised the seed to be known to the public. From his interaction with Bah Gopal, Anthony noticed that the seeds are very interesting and equally living beings to be respected. 
"I see, the seeds are interesting, the texture is also shaped. First, I see it from the esthetic way and I see it is not many people use it. Originally of aesthetic value and I see not many who use it. When think of a business, the market opportunity is still wide open. Initially from there. But when I'm getting to know deeper, it turns upside down. I don 'think about business anymore. Finally I'm trully in love with the seeds. At that time, I came to a moment, oh, the seeds is a living thing."

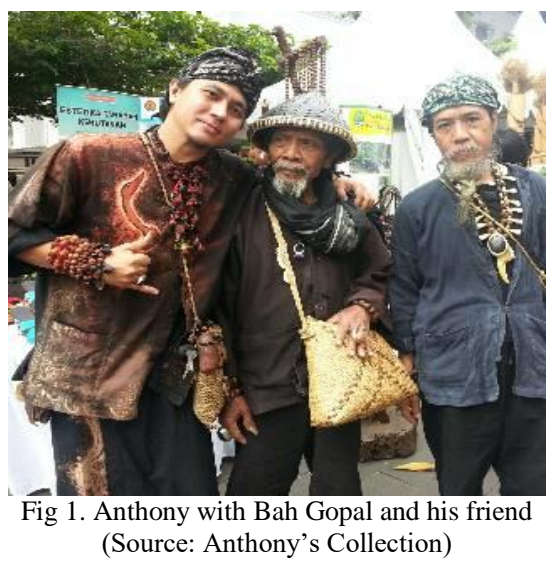

Rootedness on Sundanese culture is defined as the internalization of Sundanese culture in the individual so that the pattern of behavior is based on Sundanese cultural values. Anthony lived the roots of Sundanese culture through the internalization of its philosophical values, so that his view of life and his work is based on these philosophical values. His search results on Sundanese culture he acquired through social interaction and search independently through written sources, opened his insight that Sundanese had local wisdom values that are very noble, especially those related to the natural environment, which Anthony favored.

"The most I like and most of all about the local wisdom of the philosophy of life of the Sundanese, are cageur, bageur, bener, singer, pinter. It's the main thing that should always be tried and it's not easy. It will collide with our ego, by principle, with emotion."

Anthony's proximity to nature makes him interpret kasundaan as the harmony of life with nature. The meaning appears in line with Anthony's findings on Sundanese culture which he finds in various literatures that in Sundanese culture all things are filled with simplicity accompanied by humility, namely to assume that he is with the same nature, that is living things that live on earth, not may dominate nature, but must live in harmony with nature, because nature has set it all, just living humans who must be able to balance themselves.

Based on his understanding, Anthony believes that Sundanese cultural philosophy can be used as a guide of life. Therefore, he chose a representative way to show his love for Sundanese culture by elevating the values of local wisdom that is in harmony with nature through seed, which is processed into accessories such as bracelets, necklaces and others to beautify the appearance.

According to Anthony, philosophically, seeds are the core source of life, which must be respected.

"Appreciate the beans, we automatically appreciate the tree, appreciate the ropes, automatically appreciate the manufacturer, appreciate the manufacturer, yes we respect others. One of the essences that must be raised in us speak Sundanese culture or any other culture, the positive value of traditional culture or ancient culture that is appreciate."

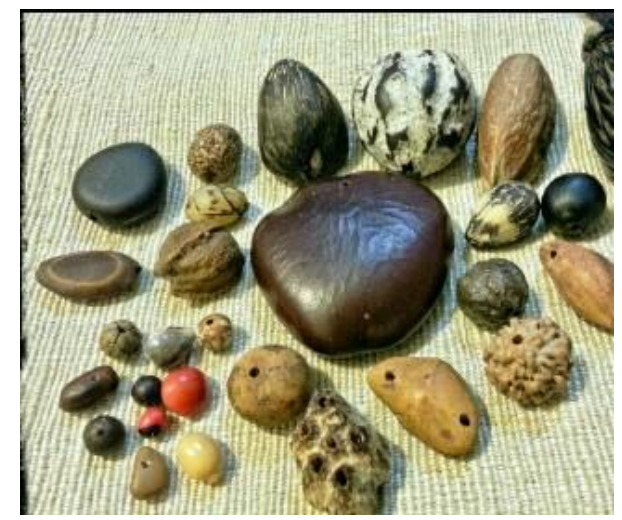

Fig. 2. Various types of seeds used as accessories material (source: bumi putih)

Anthony's journey became an accessory artist, beginning in 2009. At that time, Anthony and some friends formed Pakuan Kriya Waruga, a nonprofit collection originally intended as a gathering place. The name that implies the house where the true man works, is intended as a place of work for people who want to work and be friendly with nature.

Although it is no longer used as an identity in the work, the name Pakuan Kriya Waruga still remain use in social media Facebook. The concept of Pakuan Kriya Waruga which is understood as the concept of the unity of the soul and body of man who realized his role in the world, is now run by Anthony with his team in Putih Spiritual Jewelry by producing necklace and bracelet accessories from natural seeds. Regarding the purpose of his work, Anthony explains it as follows,

"We live to be reciprocally on the earth. What is the reciprocity? One of them works for the earth, finally united with the earth. Right. We're part. What is our role? We need to find out what our role is and we must do it as much as possible in our role."

According to Fritz Heider (in Littlejohn \& Foss, 2009: 548) "People have reasons for the way they behave". There is always a reason in every human behavior. Thus, no human behavior is unreasonable or purposive.

For Anthony, as a fellow creature, maintaining harmony with nature means the mutual respect between nature and man, including the aspect of honesty that must be held firm. It is applied in the work and treat his work. 
Besides through his works, Anthony's appreciation to Sundanese culture is also manifested by wearing Sundanese clothes, in the form of pangsi and Sundanese head iket in everyday life as he works. Not to be missed, Anthony wore bracelets and necklaces from his own seeds as a way of introducing seeds to people since 2010.

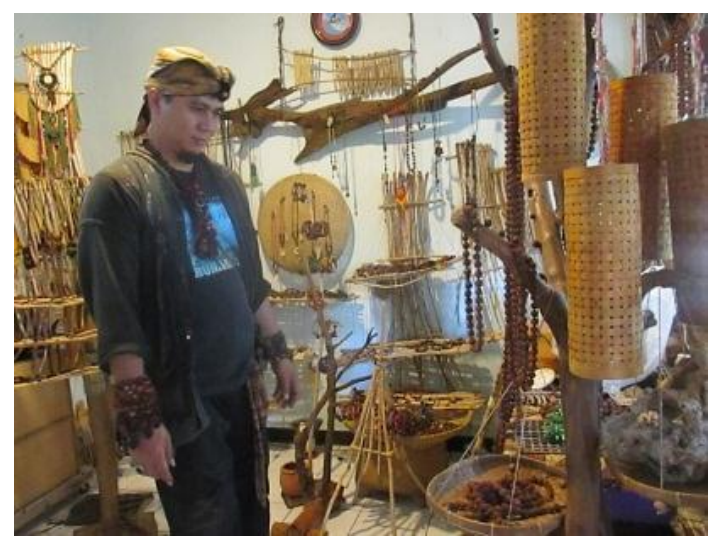

Fig. 3. Anthony among his works displayed in Tahura (Source: private collection)

More specifically, the philosophy of Bumi Putih in work is as follows:

Cageur (healthy); The values of simplicity and very in harmony with nature contained in the local wisdom of Sundanese culture became our inspiration in the work. The desire to invite learning together to live in harmony with nature and to be grateful for the beauty of life itself becomes a mission that we stretcher.

Bageur (pleasant); Seed as the beginning of a life becomes our choice in accompanying our work. To learn to value life more, we did not pick, but picked up the fallen ones. We also do not use chemicals and minimal electrical machines in the process of work.

Bener (trustworthy); In the creation of the work, we chose the ropes with the technique of summarizing as symbols of simplicity and balance between inventiveness, taste and sustained intention. Our design inspiration is born from the beauty and majesty of nature and the values of local wisdom of Sundanese culture, which makes each of our work has a meaningful soul.

Pinter (intelligent); Along with our growing process, we found that the seeds are not only beautiful and unique, but have bio energy that is beneficial for both body and soul health when worn. We continue to explore in finding stories, myths, legends and research on the benefits of whole seeds

Singer (conscientious); Formed from 2009, as a venue to learn to express jealousy in a living work by cultivating flavors and balancing with nature.

\section{B. Accessories as a form of Economic Valuable Entities}

Despite of an artworks, the accessories that Anthony created ia $\mathrm{s}$ valuable economic entities. Therefore, the utilization of social media was aims not only as a media promotion for arworks, but as well as a media for selling. Eventhough it was a media for selling, but with an elegant and artistic works of arts, the content of accesories pictures uploaded on social media, doesn't look as a media for selling.

\section{Accesories as a Form of Communication}

Anthony shows his Sundanese through the work of accessories made from natural seeds strung with nylon yarn using rope techniques. For Anthony, nature has a very close relationship with the Sundanese people. Because for the Sundanese people, especially Sunda wiwitan, humans are part of nature and equally God's creatures so that humans must maintain harmony or balance of life with nature. Nature teaches many life lessons, including about the origin of man and for Anthony, the seed represents the origin of life.

"I try to introduce to people that seeds are also the same as modern jewelry. The value of each seeds was actually not inferior to modern values, the nominal value. The only difference is that seed is more to the value of life, philosophical, that this is the beginning of everything. This is the seeds of life. That's what I want to introduce."

In addition, using his own accessories is a way of communicating Anthony's work. Anthony's hands and neck were filled with accessories he had made especially for himself. Anthony felt, such a way effectively provoke people to ask about the accessories he wears.

"Until now, its very effective. Using it just like this, quite a lot of people asking me what is it? At that time, people were easiest to say, "Oh, it is from the seed.. is it?" while holding it. How is the tree look like? I can do direct promotion to the people I don't know. Immediately introduced what the seed is. Quite often. It works."

\section{Social Media: Ngigelan Jaman (adaptive)}

The media has an important role in communicating the culture to the outside community. According to Zaini Alif (2009), for the people of Sunda, in its cultural context, media is an integral part of Sundanese culture itself. Utilization of media can be said is the main event of dialogical interaction between existing community groups. In short, the media in traditional ethnic societies are "oral media", "ear media", "eye media", and "show media", where text, sounds and visual representations are delivered simultaneously in one art show.

In the modern society-based industry which is usually characterized by the development of science and technology progress, complete with the economic and political system more free and open, and has a system of education that reach out to the wider community, "media culture" has true meaning. This is a society that utilizes the media (information) to the maximum so that everyday life would be paralyzed when the existence of modern media is missing out from the community.

This condition is used by Anthony to use social media as a means of communication about the work and events associated with kasundaan. In this context, the attempts that 
communication. In many ways, the relationship between culture and communication is reciprocal and influence each other.

According to Yoshikawa (1988: 150), Hall reminds that culture affects how people think and what he thinks. What was discussed, how to talk about it and what he saw helped shape and define as well as revive a culture. Culture will not live without communication and the communication will not live without culture, each can not be changed without causing changes to the other.

Culture is dynamic, always changing as the times, the thoughts and human needs. The change can lead to an improvement, or lead to extinction. Changes that lead to extinction is feared. If not maintained, then slowly, the culture will be lost eroded by time.

Through social media, Anthony attempts to achieve two things, preserving the values of Sundanese local wisdom, as well as media promotion of his works that shows richness of the local culture as a heritage that needs to be maintained in order not to disappear. Through his skills in cultivating seeds into accessories with arts value dan use value, Anthony makes the relationship between culture and communication is represented by social media to be a synergy that support each other.

\section{REFERENCES}

[1] A.C. Alwasilah, Pokoknya Kualitatif: Dasar-Dasar Merancang dan Melakukan Penelitian Kualitatif. Jakarta: Pustaka Jaya, 2008.

[2] A.C.S. Hadi, "Melestarikan Kearifan Masyarakat Tradisional (Indigenous Knowledge)", Buletin Perpustakaan dan Informasi: Bogor, pp. 27-32, Juni 2006.

[3] A.M. Kaplan, M. Haenlein, "Users of the World, Unite! The Challenges and Opportunities of Social Media". Business Horizons, 2010, 53(1): pp. 59-68.

Fig. 4. Anthony's work of arts he uploaded to his Facebook account (source: facebook.com)

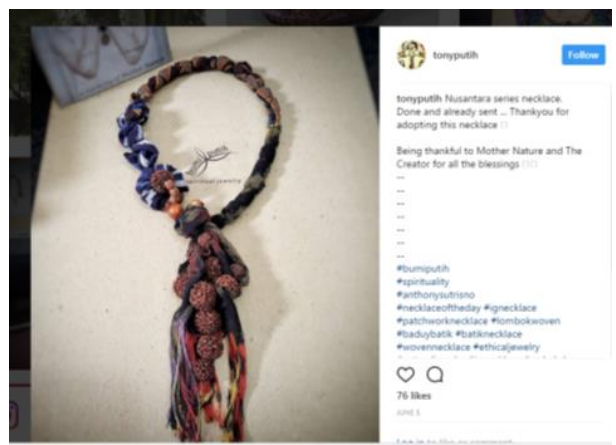

Fig. 5. Anthony's work of arts he uploaded to his Instagram account (source: @ Anthonyputih)

\section{CONCLUSION}

Culture and communication are inseparable, because culture not only determines who talks with whom, about whom, about what and how people interpret the message. Culture is the foundation of communication. When culture is diverse, there is a wide various practices of communication (Mulyana, 2006: 18). Edward T. Hall in Mulyana and Solatun (2007: 88) stated that communication is culture and culture is
[4] B. Mitchell, B. Setiawan, D.H. Rahmi. Pengelolaan Sumberdaya dan Lingkungan. Yogyakarta: Gajah Mada University Press. 2003.

[5] Budiwiyanto, "Tinjauan Tentang Perkembangan Pengaruh Local Genius dalam Seni Bangunan Sakral (Keagamaan) di Indonesia”. Ornamen, 2006, 2 (1): pp. 25-35.

[6] D. Mulyana dan Solatun. Metode Penelitian Komunikasi. Contoh-contoh Penelitian Kualitatif dengan Pendekatan Praktis. Bandung: Remaja Rosdakarya, 2007.

[7] D. Mulyana, Metodologi Penelitian Kualitatif. Bandung: Remaja Rosdakarya, 2006.

[8] Departemen Pendidikan Nasional. Kamus Besar Bahasa Indonesia Edisi Keempat. Jakarta: Gramedia Pustaka Utama, 2008.

[9] E. Kuswarno, Fenomenologi. Bandung: Widya Padjadjaran, 2009.

[10] J.W. Creswell, Qualitative Inquiry and Research Design: Choosing Among Five Traditions. USA: Sage Publication Inc. 1998.

[11] K. Adimiharja, Petani: Merajut Tradisi Era Globalisasi. Bandung: Humaniora, 2004.

[12] L.J. Moleong Metodologi Penelitian Kualitatif. Bandung: Remaja Rosdakarya, 2006.

[13] S. Hidayat, Ramuan tradisional ala 12 etnis Indonesia. Jakarta: Penebar Swadaya, 2005.

[14] T. Mumfangati, dkk.. Kearifan Lokal di Lingkungan Masyarakat Samin Kabupaten Blora Jawa Tengah. Yogyakarta: Kementerian Kebudayaan dan Pariwisata, 2004.

[15] T.O.S. Aulia, A.H. Dharmawan, "Kearifan Lokal dalam Pengelolaan Sumberdaya Air di Kampung Kuta". Sodality: Jurnal Transdisiplin Sosiologi, Komunikasi, dan Ekologi Manusia. 2010, 4 (3): pp. 345-355. 